\title{
Dopamine Turnover in Schizophrenia Before and after Haloperidol Withdrawal CSF, Plasma, and Urine Studies
}

\author{
M. Beuger, M.D., D. P. van Kammen, M.D., Ph.D., M. E. Kelley, M.S., and J. Yao, Ph.D.
}

The dopamine hypotheses of schizophrenia and antipsychotic drug action suggest that the dopamine metabolite homovanillic acid (HVA) should change with drug withdrawal and change in clinical state. We designed a study of cerebrospinal fluid (CSF), plasma, and urinary HVA on and off haloperidol to examine the effects of drug withdrawal. CSF and plasma HVA samples were obtained in 72 healthy schizophrenic (DSM-III-R) males (age: $36 \pm$ 7.4 years), before and after haloperidol withdrawal, which was after 6 weeks on placebo or sooner if they met specific criteria for relapse. We collected three 24-hour urine samples in 34 of these patients. In addition, CSF HVA was obtained in 24 well-screened age-matched male normal controls. HVA was measured with high-pressure liquid chromatography (HPLC). CSF HVA decreased significantly after drug withdrawal, particularly in those who met relapse criteria; drug-free CSF HVA levels were not significantly different from those of normals. Plasma HVA increased significantly after haloperidol withdrawal in relapsing patients, but not in clinically stable patients. Urinary HVA excretion decreased after withdrawal with decreased HVA clearance. We conclude that haloperidol withdrawal had a strong effect on dopamine turnover, whereas the patient's clinical state had only a weak central effect, without affecting total body production of HVA. Conceivably, dopamine involvement in schizophrenia reflects the failure of the homeostatic mechanisms that allow for integration of different functional brain components as needed. [Neuropsychopharmacology 15:75-86, 1996]
KEY WORDS: Homovanillic acid; Cerebrospinal fluid; Urine; Plasma; Schizophrenia; Haloperidol treatment; Drug withdrawal

For decades increased dopamine activity has been considered the major etiologic factor of psychotic symptoms (Davis et al. 1991) an assumption based on the observation that antipsychotic drugs block dopaminergic receptors (Carlsson and Lindqvist 1963; van Rossum 1966; Randrup and Munkvad 1972). However, the ini-

From the Highland Drive Veterans Affairs Medical Center (DPvK, MEK, JY), Pittsburgh, PA; and the Western Psychiatric Institute and Clinic (MB, DPvK, JY), University of Pittsburgh School of Medicine, Pittsburgh, PA

Address correspondence to Dr. van Kammen, Professor of Psychiatry, Chief of Staff, Veterans Affairs Medical Center, 7180 Highland Drive, Pittsburgh, PA 15206.

Received April 27, 1995; revised August 18, 1995; accepted August 21, 1995. tial conceptualization of psychosis as a hyperdopaminergic state was found to be too simplistic an explanation (van Kammen 1979; Davis et al. 1991). Moreover, other neurotransmitters, such as norepinephrine (van Kammen et al. 1989) and serotonin (van Kammen et al. 1995, in press), have been implicated in the relapse process.

The major dopamine metabolite in humans, homovanillic acid (HVA), has been extensively studied in relatively small patient samples without settling the issue as to whether an increase in central dopamine metabolism is reflected in cerebrospinal fluid (CSF), plasma (Amin et al. 1992; Kahn and Davidson 1993; Koreen et al. 1994), or urine (Contreras et al. 1987, 1988; Maas et al. 1979, 1993a, 1993b). In addition, HVA may appear as a byproduct of norepinephrine synthesis (Scheinin 1986; Kopin et al. 1988a; Lambert et al. 1994, 1993). CSF HVA levels in schizophrenic patients are reportedly not different from those of normal control subjects (Post et 
al. 1975; Nybåck et al. 1983; Pandey et al. 1987; Pickar et al. 1990; Maas et al. 1993a; Hsiao et al. 1993) although Lindström (1985) found lower CSF HVA values in chronic patients. In spite of a lack of difference compared to normals, relatively high CSF HVA values have been associated with relapse in premorbid well-functioning patients (Post et al, 1975), with paranoid patients (Rimon et al. 1971), and a positive family history of schizophrenia (Sedvall and Wode-Helgodt 1980), but lower values correlate with Schneiderian symptoms (Bowers 1973; Post et al. 1975) and poor prognosis (Bowers 1974). Recovered patients (Post et al. 1975) had lower values with longer duration of treatment.

Plasma HVA levels in schizophrenic patients have been reported to be lower in chronic patients (Davidson and Davis 1988), not significantly different in first-episode schizophrenic patients (Koreen et al. 1994), or higher in acutely ill patients (Maas et al. 1993a) than for healthy controls. Urinary HVA levels have been reported to be similar in acutely ill patients and controls (Maas et al. 1993a) or decreased in chronic patients (Karoum et al. 1987). Others (Maas et al. 1993a; Whelton et al. 1993) did not find a difference in urinary HVA output between controls and patients. Few studies have looked at both CSF and plasma HVA under changing clinical circumstances such as before and after drug treatment (Sharma et al. 1989, 1993); none have looked at HVA in all three compartments concurrently (Linnoila et al. 1988).

Because the changes in CSF and plasma values after drug withdrawal appear to go in opposite directions [i.e., CSF HVA declines and plasma HVA increases (Pickar 1988)], we examined the interaction effects of haloperidol withdrawal and changes in clinical state on HVA levels in the different body fluid compartments. To assess whether the observed changes are not just the result of changes in clinical state and in clearance between the different compartments (CSF, plasma), we also calculated renal HVA clearance and measured total HVA production (Contreras et al. 1987, 1988). To overcome other sources of variance in CSF (van Kammen and Sternberg 1980; Potter et al. 1984; Csernansky et al. 1988a; Doran et al. 1990; Koreen et al. 1994); plasma (Kendler et al. 1983, Davidson et al. 1987), and urinary HVA (Karoum et al. 1987), we standardized for time of day for blood draws and lumbar punctures (LPs), activity, diet, and gender. CSF HVA data of an early subset of these patients have been published in a previous study (van Kammen et al. 1989).

\section{METHODS}

\section{Subjects}

Seventy-two physically healthy male veterans with a DSM-III-R diagnosis of schizophrenia (Table 1 for demographics) entered the drug withdrawal study volun- tarily, on the Schizophrenia Research Unit at the DVA Medical Center, Highland Drive, in Pittsburgh, PA, after signing an informed consent form. Staff discussed with patients extensively the risks of drug withdrawal and previous prodromes and relapses for assessment of prodromes. Where appropriate, the procedures and risks were discussed with significant others. Only patients who had been treated for at least 6 months with antipsychotic drugs and who had experienced at least two previous relapses were invited to participate. Those with risk of suicide or severe violence, based on past history, were excluded. Clinical appropriateness, informed consent, diagnosis and demographic data of each potential participant were reviewed prior to research participation by a consensus meeting of the clinical staff. The Investigational Review Board (IRB) monitored the informed consent process. If the patients were not treated with haloperidol, they were switched to this drug for at least 2 months prior to testing. If patients were on long-acting agents, oral haloperidol replacement was given for at least 2 months. Patients adhered to a low-monoamine, caffeine-restricted and alcoholfree diet. After signing informed consent, patients received haloperidol in unmarked capsules. Haloperidol dose changes were completed and antiparkinsonian agents were discontinued at least 2 weeks before the first LP (Table 1 for dosages). Following this LP, haloperidol was discontinued between 2 and 10 days and replaced overnight with placebo. A second LP was performed after 6 weeks of placebo treatment or when patients met criteria for relapse (mean $28.7 \pm 12.1$, range 14-58 days). These specific criteria consisted of a mean increase over 3 consecutive days of three points or more on the 15-point psychosis item of the Bunney-Hamburg rating scale (Bunney and Hamburg 1963) over the mean during the last week of drug treatment. Forty patients remained clinically stable and participated in the research procedures after 6 weeks of placebo, 32 patients met relapse criteria before the completion of this period. After the patients completed the protocol or dropped out, they received antipsychotic drug treatment as indi-

Table 1. Demographics and Clinical Data of All Patients $(n=72)$

\begin{tabular}{lcc}
\hline & Mean \pm SD & Range \\
\hline Age (years) & $36.15 \pm 7.39$ & $20-50$ \\
Age of onset (years) & $23.44 \pm 4.85$ & $13-351$ \\
Duration of illness (years) & $12.72 \pm 6.79$ & $0.5-29^{a}$ \\
Height (cm) & $174.43 \pm 7.28$ & $158-191$ \\
LP weight haloperidol (kg) & $82.77 \pm 17.15$ & $56.3-134$ \\
LP weight drug free (kg) & $83.46 \pm 17.11$ & $57.8-136.4$ \\
Dose haloperidol (mg/day) & $11.28 \pm 7.24$ & $2-40^{b}$ \\
Days drug free prior to LP & $38.61 \pm 12.65$ & $14-67$ \\
\hline
\end{tabular}

"DSM-III-R criteria require that symptoms be present for at least 6 months.

'One patient received $40 \mathrm{mg}$ haloperidol PO QD. 
cated and returned to outpatient treatment. After the protocol was completed and the patients restabilized, the staff discussed with each patient the medication and the behavioral changes throughout his participation.

\section{Normal Control Subjects}

Twenty-four carefully screened and age-matched male control subjects (age $35 \pm 10$ years) were recruited from the community. They were free of psychiatric [SADS-L (Spitzer and Endicott 1979)] or medical illnesses (present or past) and without family history of psychiatric illness. Subjects also passed a urine drug screen. They received an LP after an overnight stay in the hospital under the same standard conditions as the patients. They signed IRB-approved informed consent forms explaining the purpose and risks of research participation and their right to withdraw.

\section{Lumbar Puncture}

The LP was performed between 7:30 and 8:30 A.M. after overnight bed rest (van Kammen and Sternberg 1980) with the subject fasting and without smoking from 11:00 P.M. the previous evening until the completion of the procedure, with the patient in the lateral decubitus position. CSF was collected in three pools of $12 \mathrm{ml}$ each in ice-chilled tubes. Each of these pools was thoroughly mixed and subsequently aliquotted in $0.5-$ and $1-\mathrm{ml}$ tubes and stored at $-80^{\circ} \mathrm{C}$ until assayed. CSF from the first pool was used for HVA measurements.

\section{Blood Draws}

Blood draws for plasma HVA were performed at 8:00 A.M., with the subject remaining at bed rest, fasting, and nonsmoking from 11:00 P.M. the previous evening until the completion of the procedure. An 18-gauge IV intracatheter or a 19-gauge butterfly needle was inserted 30 minutes before the first blood draw was obtained. An IV of $500 \mathrm{cc}$ normal saline solution was run at a Keep Vein Open rate between blood draws. The technician then processed the whole blood and pipetted the plasma into nunc tubes containing 1 to $2 \mathrm{ml}$. The tubes were then immediately stored in a $-80^{\circ} \mathrm{C}$ freezer.

\section{Urine Collection}

Twenty-four-hour urine specimens were collected in the 3 days leading up to the LPs in the last 34 of the 72 patients. If collections were less than $900 \mathrm{ml}$ or creatinine levels indicated an inadequate collection, the urine was discarded and an additional 24-hour urine was obtained. Urine was placed in containers with concentrated $\mathrm{HCl}$ and refrigerated at $4{ }^{\circ} \mathrm{C}$ immediately after voiding. Aliquots of the 24-hour urine collections were stored at $-20^{\circ} \mathrm{C}$ until assayed. Creatinine levels in plasma and urine were obtained.

\section{Assays}

HVA was determined in CSF, plasma, and urine with high-pressure liquid chromatography (HPLC) utilizing the modified procedures of Scheinin et al. (1983), Gerhardt et al. (1986), and Binder and Sivorinovsky (1984), respectively. Intraassay coefficients of variation were $3.32 \%$ at a concentration of $26.75 \mathrm{ng} / \mathrm{ml}$ for CSF, $6.59 \%$ at a concentration of $27.81 \mathrm{ng} / \mathrm{ml}$ for plasma, and $7.5 \%$ at a concentration of $1.77 \mu \mathrm{g} / \mathrm{ml}$ for urine. Interassay coefficients of variation were $4.41 \%$ at a concentration of $26.75 \mathrm{ng} / \mathrm{ml}$ for CSF, $6.96 \%$ at a concentration of $27.81 \mathrm{ng} / \mathrm{ml}$ for plasma, and $11.12 \%$ at a concentration of $1.77 \mu \mathrm{g} / \mathrm{ml}$ for urine. CSF, plasma, and urinary HVA measures did not correlate with storage time in days.

\section{Clearance}

Urine volume, plasma creatinine, and creatinine concentration were obtained as concurrent measures of kidney function in order to control for possible effects on HVA clearance. HVA and creatinine clearance were calculated according to the following formula (Maas et al. 1993a), $c l=V C / P$ where $c l$ is creatinine clearance, $V=$ urinary volume, $C=$ urinary concentration, excretion is $V C$, and $P$ is plasma concentration.

\section{Statistical Analysis}

Analysis of variance (ANOVA) was performed to assess relapse, medication, and interaction effects of CSF, plasma, and urinary HVA levels, urinary output of HVA and creatinine, urine volume, and HVA and creatinine clearance. Pearson correlation coefficients were used to determine relationships between demographics, psychosis, and HVA. Student $t$-tests (paired when appropriate) were used to analyze differences between groups. All tests were two-tailed. Initial inspection of the distributions of HVA variables indicated that plasma HVA had a slightly skewed distribution, thus the values were log-transformed for the purpose of analysis.

\section{RESULTS}

\section{Demographics}

CSF HVA correlated significantly with age on $(r=$ $-0.25, p=.033)$ and off haloperidol $(r=-0.31, p=.008)$, but plasma HVA and the urinary measures did not. None of the drug-free HVA measures were significantly correlated with the time drug free before procedures. 


\section{Medication and Clinical Change Effects}

Mean CSF HVA values for all 72 subjects were significantly lower after haloperidol withdrawal than before $(30.95 \pm 15.18 \mathrm{ng} / \mathrm{ml}$ versus $27.17 \pm 12.13 \mathrm{ng} / \mathrm{ml} ; F=$ $6.94, \mathrm{df}=(1,70), p=.01)$, indicating a significant medication effect without a relapse or interaction effect (Table 2).

Analysis of plasma HVA values did reveal a marginally significant interaction effect $(F=2.92, \mathrm{df}=(1,70)$, $p=.092)$, showing that patients who had an increase in symptoms following haloperidol withdrawal had increases in plasma HVA, whereas those who remained clinically stable had no significant change in plasma levels (Table 2).

Mean urine volume decreased significantly after haloperidol withdrawal $(3.10 \pm 1.40$ versus $2.42 \pm 1.35 \mathrm{~L} /$ day; $F=5.23$, df $=(1,32), p=.03)$, but mean urinary HVA concentration did not $(1.47 \pm 1.05$ versus $1.41 \pm$ $0.95 \mu \mathrm{g} / \mathrm{ml} ; F=0.14, \mathrm{df}=(1,32), p=\mathrm{NS})$. Mean urinary HVA excretion decreased significantly after haloperidol withdrawal $(3.60 \pm 2.00$ versus $2.66 \pm 1.54 \mathrm{mg} /$ day; $F=17.02, \mathrm{df}=(1,32), p<.0005)$, suggesting that total body production is reduced. HVA clearance also decreased significantly after haloperidol withdrawal $(857.99 \pm 670.86$ versus $527.47 \pm 362.47 \mathrm{~L} /$ day; $F=$ $13.09, \mathrm{df} \pm(1,32), p=.001)$. However, because of a large variance difference between clinical status groups, the ANOVA effects on clearance are tentative.

Urinary creatinine concentration increased significantly following haloperidol withdrawal (607.55 \pm
246.07 versus $829.91 \pm 430.46 \mu \mathrm{g} / \mathrm{ml} ; F=7.16, \mathrm{df}=$ $(1,28), p=.012)$, while the urine volume decreased (see before). Therefore, no significant change in total creatinine output was observed after drug withdrawal $(1632.45 \pm$ 408.06 versus $1554.56 \pm 473.47 \mathrm{mg} /$ day; $F=0.15, \mathrm{df}=$ $(1,28), p=N S)$. Urinary creatinine clearance did not change significantly following haloperidol withdrawal $(164.00 \pm 50.01$ versus $160.61 \pm 45.87 \mathrm{~L} /$ day; $F=0.06$, $\mathrm{df}=(1,26), p=\mathrm{NS})$. These measures provided evidence that kidney function was not impaired in our patients.

\section{Comparison with Controls}

CSF HVA was not significantly different between drugfree patients and normal comparison subjects. The relationships among the different compartments with alternating clinical state and medication status are shown in Table 3.

\section{Relationships with Psychosis}

Only drug-free CSF HVA values showed a significant (negative) correlation with global psychosis (Bunney and Hamburg 1963) at the time of procedures.

\section{DISCUSSION}

Our data indicate that haloperidol withdrawal markedly decreased HVA function and excretion in schizo-

Table 2. CSF and Plasma in Normal Control Subjects and in Schizophrenic Patients during Haloperidol Treatment and after Haloperidol Withdrawal

\begin{tabular}{|c|c|c|c|}
\hline & $\begin{array}{l}\text { Haloperidol } \\
(\text { mean } \pm \text { SD) }\end{array}$ & $\begin{array}{c}\text { Drug Free } \\
(\text { mean } \pm \text { SD) }\end{array}$ & $n$ \\
\hline \multicolumn{4}{|c|}{ CSF HVA (ng/ml) } \\
\hline Normal subjects & NA & $28.41 \pm 12.01$ & 24 \\
\hline Nonrelapsers & $31.76 \pm 16.67$ & $29.32 \pm 1328$ & 40 \\
\hline Relapsers & $29.93 \pm 13.27$ & $24.49 \pm 10.10$ & 32 \\
\hline \multicolumn{4}{|c|}{ Plasma HVA $(\mathrm{ng} / \mathrm{ml})^{a}$} \\
\hline Nonrelapsers & $6.81 \pm 3.91$ & $6.31 \pm 2.52$ & 40 \\
\hline Relapsers & $5.43 \pm 2.66$ & $6.68 \pm 3.52$ & 32 \\
\hline \multicolumn{4}{|c|}{ Urinary HVA-total (mg/day) } \\
\hline Nonrelapsers & $4.02 \pm 2.22$ & $3.09 \pm 1.75$ & 13 \\
\hline Relapsers & $3.34 \pm 1.86$ & $2.40 \pm 1.37$ & 21 \\
\hline \multicolumn{4}{|c|}{ Urinary HVA-conc. $(\mu \mathrm{g} / \mathrm{ml})$} \\
\hline Nonrelapsers & $1.72 \pm 1.10$ & $1.71 \pm 1.12$ & 13 \\
\hline Relapsers & $1.31 \pm 1.01$ & $1.22 \pm 0.80$ & 21 \\
\hline \multicolumn{4}{|c|}{ Urinary HVA-clearance (L/day) } \\
\hline Nonrelapsers & $963.27 \pm 912.57$ & $564.34 \pm 408.33$ & 13 \\
\hline Relapsers & $792.81 \pm 480.89$ & $504.64 \pm 339.58$ & 21 \\
\hline
\end{tabular}

Abbreviations: HVA = homovanillic acid, urinary HVA-total $=$ total urinary HVA in $\mathrm{mg} /$ day (mean of 3 -day collection, urinary HVA-conc. $=$ urinary HVA concentration in $\mathrm{mg} / \mathrm{L}$, urinary HVA clearance $=(\mathrm{vol}$ ume $\times$ HVA-conc.) $/$ plasma concentration, $\mathrm{CSF}$ HVA $=$ cerebrospinal fluid HVA.

No relapse effects or relapse $\times$ medication effects were observed.

"Values log transformed for analysis. 
Table 3. Relationships between HVA Measures in the Different Compartments, on and off Haloperidol

\begin{tabular}{|c|c|c|c|}
\hline & Plasma HVA & $\begin{array}{c}\text { Urinary } \\
\text { HVA-conc. }\end{array}$ & $\begin{array}{c}\text { Urinary } \\
\text { HVA-total }\end{array}$ \\
\hline \multicolumn{4}{|l|}{ Haloperidol } \\
\hline \multicolumn{4}{|l|}{ Relapsers } \\
\hline CSF HVA & 0.24 & -0.32 & -0.05 \\
\hline Plasma HVA & & -0.07 & -0.00 \\
\hline Urinary HVA-conc. & & & $0.84^{\prime \prime}$ \\
\hline \multicolumn{4}{|l|}{ Nonrelapsers } \\
\hline CSF HVA & 0.08 & 0.01 & -0.05 \\
\hline Plasma HVA & & -0.16 & -0.21 \\
\hline Urinary HVA-conc. & & & $0.93^{\prime \prime}$ \\
\hline \multicolumn{4}{|l|}{ Drug free } \\
\hline \multicolumn{4}{|l|}{ Relapsers } \\
\hline CSF HVA & $0.377^{i 7}$ & $-0.44^{i i}$ & $-0.44^{n}$ \\
\hline Plasma HVA & & -0.04 & -0.13 \\
\hline Urinary HVA-conc. & & & $0.76^{a l}$ \\
\hline \multicolumn{4}{|l|}{ Nonrelapsers } \\
\hline CSF HVA & 0.15 & 0.06 & -0.06 \\
\hline Plasma HVA & & 0.23 & 0.20 \\
\hline Urinary HVA-conc. & & & $0.73^{n}$ \\
\hline
\end{tabular}

Abbrevations: HVA = homosamillic acid, CSF HVA = cerebrospinal fluid HVA, urinary HVA-conc. = urinary HVA concentration in mg/L, urinary HVA-total = total urinary HVA in mg/day (mean of 3-day collection).

" $p<.05$.

phrenic patients. Change in psychosis (i.e., relapse status), however, had a very limited effect. CSF HVA and renal HVA excretion declined with drug withdrawal regardless of clinical change. Plasma HVA increased significantly which could be due to the increased transfer out of the CSF and decreased renal clearance. Plasma HVA increased mainly in those who met relapse criteria. We found that CSF HVA decreased slightly more and plasma HVA increased significantly in those who met relapse criteria compared to those who remained clinically stable following drug withdrawal (Figure 1). Patients who showed a symptom exacerbation and those who remained clinically stable were not different in age, age of onset, duration of illness, or premorbid functioning (data not shown). Psychosis correlated negatively with CSF HVA but not significantly with plasma HVA. The correlations between HVA in the different compartments were stronger in the relapsers (on and off haloperidol) and particularly in the drug-free relapsers. This suggests that during relapse, brain HVA contributes more to HVA in plasma and urine, whereas during clinical stability central dopamine turnover is not related to plasma or urinary HVA.

\section{How Do CSF, Plasma, and Urinary HVA Relate to Brain Dopamine Turnover?}

To interpret the observed changes in steady-state HVA after drug withdrawal and relapse, we need to take into account the origins and metabolism of HVA as well as the adaptive changes in the dopaminergic system caused by chronic haloperidol administration. Because plasma HVA does not enter the CSF (Elchisak et al. 1978), CSF HVA is believed to be exclusively of central origin. However, studies in rats suggest that only approximately $3.5 \%$ of brain HVA ends up in the CSF (Aizenstein and Korf 1978). In primates the percentage of brain HVA going to the CSF may be larger because of a larger cortical dopamine pool than in rodents (Stanley et al. 1985; Elsworth et al. 1987).

Most of the brain HVA enters directly into the blood supplying some of the plasma HVA (Kopin et al. 1988b; Lambert et al. 1993; Maas et al. 1993b). The rest of plasma HVA may be derived from peripheral noradrenergic neurons (Hoedtke et al. 1974; Kopin et al. 1988b; Maas et al. 1993b). Plasma HVA has long been believed to be a measure of central dopaminergic activity in humans (Cutler et al. 1982; Sternberg et al. 1983; Sharma et al. 1989). Some changes in plasma HVA reflect changes in activity in the presumed central regions of origin: the subcortical structures, in particular the basal ganglia (Lambert et al. 1993).

Twenty-five percent of urinary HVA originates in the central nervous system (Maas et al. 1979; Kopin et al. 1988a), with the remaining $75 \%$ coming from dopamine derived from peripheral noradrenergic neurons metabolized in the liver (Andèn and Grabowska-Andèn 1983; Maas et al. 1993b; Lambert et al. 1994). Loss of dopa- 

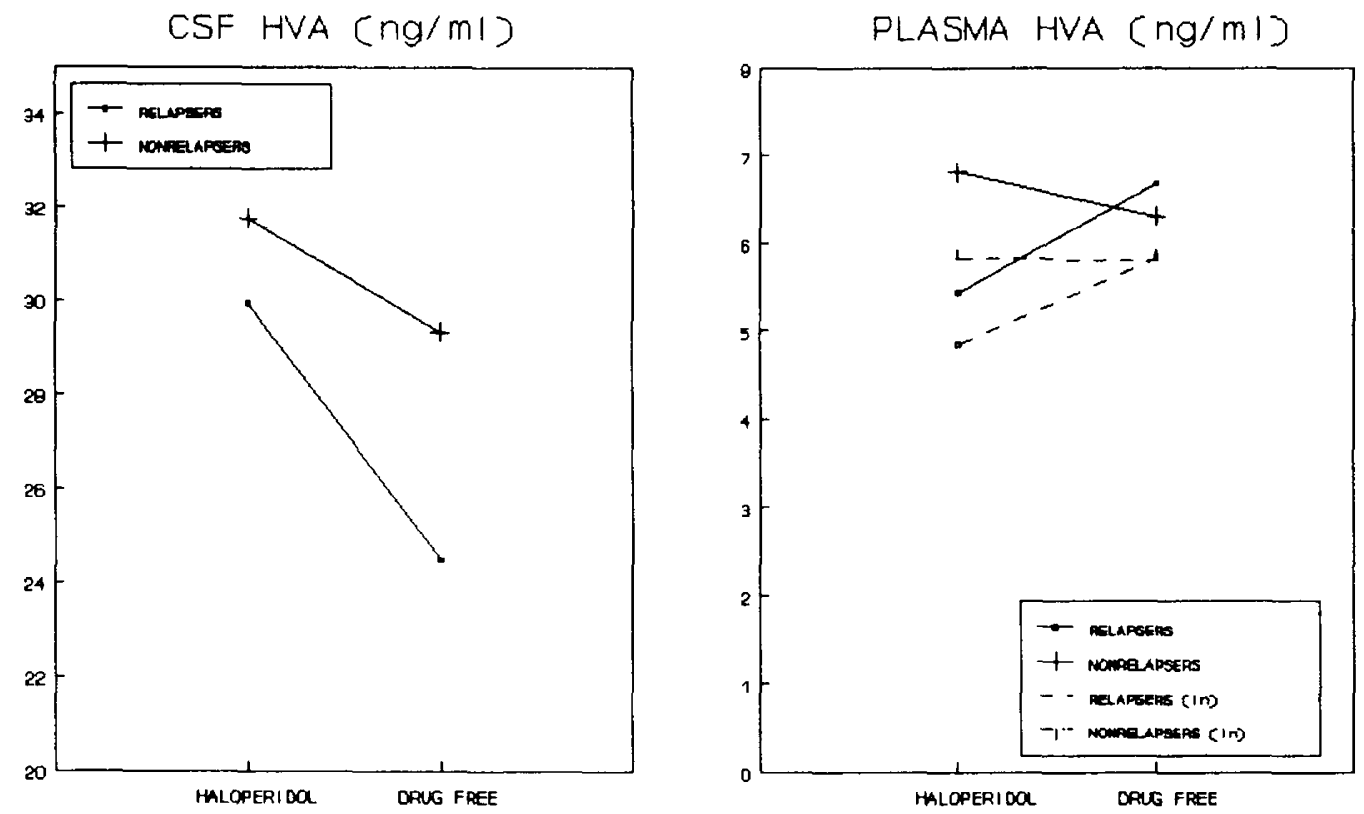

Figure 1. Haloperidol withdrawal: repeated-measures ANOVA CSF and Plasma HVA. Relapsers were patients who met specific criteria for symptom increase, nonrelapsers were patients who remained clinically stable. In, natural log; plasma data were transformed for analysis and then the means were exponentiated to reconstruct the comparisons.

mine (DA) neurons results in a decrease in urinary HVA (Hoedtke et al. 1974). Plasma HVA is almost exclusively cleared by the kidneys (Miller et al. 1987) through glomerular filtration and active tubular secretion by means of an active organic anion transport system. Most likely HVA is reabsorbed in the distal tubules (Ånggard et al. 1974), because clearance decreased with a decrease in urinary flow. HVA competes with other organic anions such as 5-HIAA, and urinary $\mathrm{pH}$ affects HVA clearance (Amin et al. 1992). The antipsychotic drug effects on total urine volume (Crowley et al. 1978), HVA output (Karoum et al. 1987), HVA renal clearance (Maas et al. 1993b), and the lack of a drug effect on urinary HVA concentration have been reported before, but not the evaluation of a clinical state change effect. In the nonrelapsers the changes in plasma HVA (i.e., from the brain) may have been offset by the decreased renal clearance, but the increased brain and decreased renal clearance in the relapsers led to an increase in plasma HVA.

Traditionally, the proposed major source of CSF HVA has been the striatum, which lies in close proximity to the lateral ventricles, in addition to the putamen and the nucleus accumbens (Bacopoulos et al. 1978) based on studies in rodents (Sourkes 1973; Amin et al. 1992). However, no significant relationship was found between CSF HVA and HVA in the basal ganglia of nonhuman primates by Elsworth et al. (1987). They did find a significant correlation between cisternal CSF HVA and HVA in the dorsofrontal cortex, which may be explained by the much larger cortical production of HVA in primates than in rodents. A similar correlation between HVA in CSF and the frontal cortex was found in human autopsy studies (Stanley et al. 1985). In schizophrenic patients cortical atrophy (van Kammen et al. 1986), decreased frontal blood flow (Weinberger et al. 1988), and increased ventricle brain ratios (VBR) (van Kammen et al. 1983, 1986; Nybåck et al. 1983; Jennings et al. 1985; Houston et al. 1986; Losonczy et al. 1986; Doran et al. 1987; Lewine et al. 1991) have been associated with lower CSF HVA. In normals CSF HVA levels did not correlate significantly with VBR, nor were CSF HVA levels different from those in patients (Nybåck et al. 1983). This suggests that much of the human CSF HVA in schizophrenic patients is of frontal cortical origin.

\section{Haloperidol Withdrawal}

Haloperidol withdrawal had a significant influence on HVA levels and on urinary HVA excretion. The decrease in CSF HVA following drug withdrawal has been noted before, without defining which patients had changed clinically (Bartkó et al. 1987; Pickar et al. 1990), while a lack of changes were observed if no relapsed patients were included (Zander et al. 1981; Bagdy et al. 1985; Frecska et al. 1985). A dopamine receptor rebound following drug withdrawal in schizophrenic patients has been hypothesized but not confirmed (van Kammen et al. 1982a), which could explain the decrease in brain HVA output (Bagdy et al. 1985; Frecska et al. 1985). Recent data suggest that $D_{4}$ receptor supersensitivity could be present in schizophrenia (Seeman 1992), although it is unclear as yet how much this affects total dopamine turnover. In addition, an increase in CSF 
clearance of HVA compared to the on-haloperidol condition might also partially explain the decrease in CSF HVA. HVA is transported across the brain-blood barrier by a probenecid sensitive organic anion transport system (Moleman et al. 1978; Westerink and Kikkert 1986) that is inhibited by haloperidol.

Clinical stability at 6 weeks drug free was associated with a nonsignificant decrease in CSF and plasma HVA, which may reflect a modest drug effect on dopamine turnover. For those who relapsed a more complex pattern emerged: CSF HVA decreased and plasma HVA levels increased significantly. Because urinary HVA clearance and production declined similarly in both patient groups (Figure 2), the differences observed in CSF and plasma HVA between these groups may reflect decreased cortical or increased hippocampal input on other dopamine projection areas. It is conceivable that increased dopamine activity in subcortical areas and the temporal lobe suppressed cortical dopamine turnover (Pycock et al. 1980; Scatton et al. 1982; Haroutunian et al. 1988).

Our data provide only weak evidence that relapse may be associated with a relatively greater decrease in CSF HVA following drug withdrawal. It confirms the repeated inability to find a significant increase in CSF HVA in schizophrenic patients as evidence of dopamine overactivity. In contrast, the present-day understanding of the intrabrain dopamine dynamics suggests an early temporal lobe lesion-associated decrease in dopamine turnover in the prefrontal cortex and increased mesolimbic and striatal dopamine release (Lipska et al. 1994, in press a). That only trend level significance was

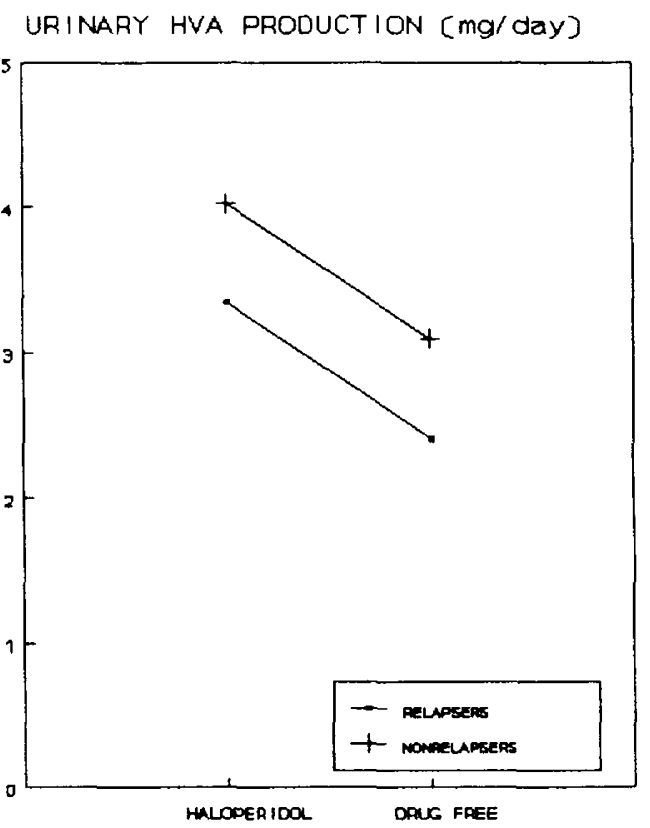

reached may be explained by an increase in variance due to the concentration gradient of HVA down the spinal cord (Sourkes 1973; Garelis et al. 1974). The potentially larger decrease in CSF HVA in relapsed patients may be explained by greater $\mathrm{D}_{2}$ (or $\mathrm{D}_{4}$ ) receptor sensitivity leading to a greater decrease in dopamine release or a greater ventral hippocampal activity in relapsed patients [Csernansky et al. 1988a]. For this hypothesis to be tested SPECT or PET measurements of dopamine receptor activity in relapsed patients may need to be obtained. So far, such data have not been forthcoming.

Several groups have reported that increases in symptoms within 3 to 6 weeks following drug withdrawal were associated with increases in plasma HVA (Pickar et al. 1986; Glazer et al. 1989; Davidson et al. 1991). In addition, plasma HVA may also differ between clinical states, if the mesolimbic brain activates the peripheral autonomic nervous system with relapse (Dawson et al. 1994) [i.e., increased peripheral dopamine converted into HVA (Andèn and Grobowska-Andèn 1983; Maas et al. 1993b; Lambert et al. 1994)]. However, peripheral autonomic arousal does not equate with psychosis but may be a mixed trait and state marker (Dawson et al. 1994; Zahn 1988).

The attenuated frontal cortical dopamine release (CSF HVA) in patients with structural or functional cortical changes (Nybåck et al. 1983; Stanley et al. 1985; van Kammen et al. 1983, 1986; Doran et al. 1983; Weinberger et al. 1988) and the relative increase in plasma HVA in relapsers may reflect decreased cortical and increased mesolimbic and temporal lobe dopamine release or activity (Sourkes 1973; Weinberger 1987; Csernansky et al.

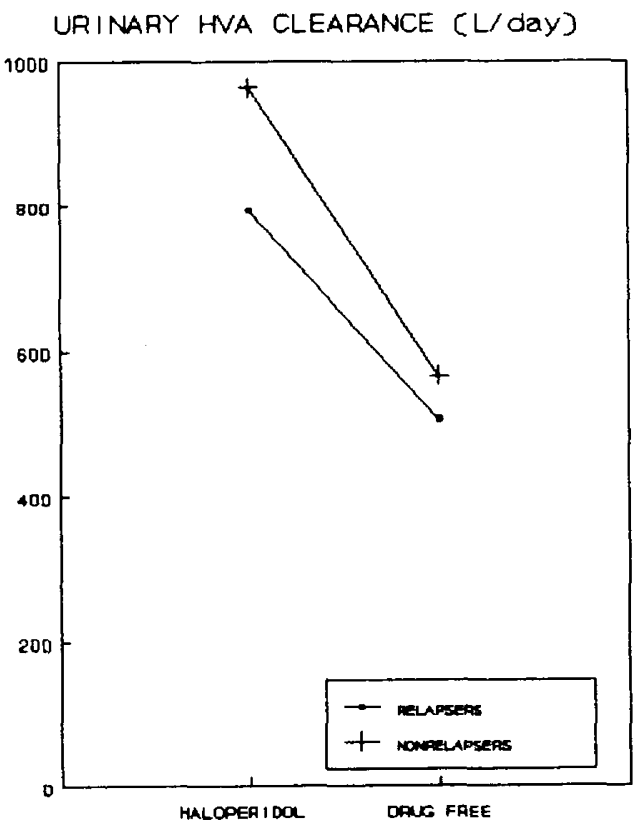

Figure 2. Haloperidol withdrawal: repeated-measures ANOVA urinary HVA production and clearance. Urinary HVA production (mg/day; mean of 3-day collection. HVA clearance (L/day), (volume $\times$ HVA-concentration)/plasma concentration. 
1988b; Gur et al. 1995). The recent studies of Lipska et al. (1992, 1993, 1994, in press b) raise an interesting possibility that neonatal lesions or temporal lobe alterations may decrease cortical and increase subcortical HVA production.

van Kammen and coworkers (van Kammen and van Kammen 1984; van Kammen et al. 1996) have proposed that the monoamine changes in relapse-prone schizophrenic patients reflect increased stress sensitivity (Antelman et al. 1988), which can be muted by antipsychotic drug treatment (van Kammen 1991) Breier et al. (1993) reported that schizophrenic patients, as compared to normal volunteers, had significantly greater 2-deoxyglucoseinduced plasma HVA increases. These plasma HVA peak changes correlated inversely with frontal cortex volume as measured with magnetic resonance imaging in the schizophrenic patients. The abnormal dopamine response to stress may be mediated through reduced cortical inhibitory influences. Plasma cortisol increases were similar in the two groups, raising the possibility that the plasma HVA response to stress is specific for schizophrenia (Breier et al. 1993). Whether our results indeed point to a greater stress sensitivity as indicated by relatively decreased CSF HVA and increased plasma HVA levels leading to an increase in psychosis or that the stress of the psychosis increase leads to these changes in dopamine release remains to be determined. The questions of how and why dopamine and schizophrenia are linked may need to be addressed in concurrent on- and off-drug evaluations of the serotonin (Meltzer 1991), the noradrenergic system (Hornykiewicz 1982, Grenhoff et al. 1993), the glutamate (Zukin and Javitt 1992), the GABA (van Kammen et al. 1982b, submitted), or the cholinergic systems (Karson et al. 1991; Tandon et al. 1991; Yeomans 1995); which all interact with or influence the dopamine system.

The changes in psychosis can now be understood in terms of changes in intrabrain dynamics or connectivity during clinical states rather than gross changes in dopamine release (Weinberger 1987; Lipska et al. in press $b$ ). Indeed, the apparent paradox of decreased CSF HVA (Bowers et al. 1980; Lindström 1985; Pickar et al. 1990)-in the absence of differences with normalsand higher plasma HVA with higher psychosis observed by others (Davis et al. 1985, Borg et al. 1985; Pickar et al. 1986; Davila et al. 1988; Maas et al. 1988; Glazer et al. 1989; Javaid et al. 1990; Muscettola et al. 1990; Baker et al. 1991; Davidson et al. 1991) with decreased urinary clearance becomes then understandable. Our data raise the additional possibility that peripheral regulation of plasma HVA is altered with relapse without clarifying the potential mechanism of this change, because haloperidol withdrawal decreased urinary clearance in all subjects. Conceivably, dopamine involvement in schizophrenia reflects the failure of homeostatic mechanisms in the brain that facilitate the integration of different functional components (van Kammen et al. 1995).

\section{ACKNOWLEDGMENTS}

The authors thank the patients and nursing staff of the Schizophrenia Research Unit under the leadership of Doris McAdam, RN, for their participation and collaboration. Rachel Zoffer was responsible for patient scheduling and sample collection and distribution. P. Zhu assisted with the HVA assays. We are grateful for the comments by Drs. Potter, Friedhoff, and Linnoila. Funding for this project was provided to Dr. van Kammen by the National Institute of Mental Health (RO1MH44-841), the Department of Veterans Affairs Research and Development Service (Merit Review), the Bataan and Corregidor Medical Research Fund, Inc., and the Highland Drive Veterans Affairs Medical Center.

\section{REFERENCES}

Aizenstein ML, Korf J (1978): Aspects of influx and efflux of homovanillic acid of rat cerebrospinal fluid. Brain Res 149:129-140

Andèn NE, Brabowska-Andèn M (1983): Formation of deaminated metabolites of dopamine in noradrenaline neurons. Naunyn Schmiedebergs Arch Pharmacol 324:1-6

Ånggard E, Lewander T, Sjöqvist B (1974): Determination of homovanillic acid turnover in man. Life Sci 15:111-122

Åntelman SM, Knopf S, Caggiula A, Kocan D, Lysle DT, Edwards DJ (1988): Stress and enhanced dopamine utilization in the frontal cortex: The myth and reality. Ann N Y Acad Sci 537:262-272

Amin F, Davidson M, Davis KL (1992): Homovanillic acid measurement in clinical research: A review of methodology. Schizophr Bull 18:123-148

Bacapoulos NG, Maas JW, Hattox SE, Roth RH (1978): Regional distribution of dopamine metabolites in human and primate brain. Commun Psychopharmacol 2:281-286

Bagdy G, Perenyi A, Frecska E, Revai K, Papp Z, Fekete MIK, Arato M (1985): Decrease in dopamine, its metabolites and noradrenaline in cerebrospinal fluid of schizophrenic patients after withdrawal of long-term neuroleptic treatment. Psychopharmacology 85:62-64

Baker N, Kirch D, Waldo MC, Bell J, Adler LE, Hattox S, Murphy R, Freedman R (1991): Plasma homovanillic acid and prognosis in schizophrenia. Biol Psychiatr 29:192-196

Bartkó G, Maylath E, Herczeg I (1987): Comparative study of schizophrenic patients relapsed on and off medication. Psychiatr Res 22:221-227

Binder S, Sivorinovsky G (1984): Measurement of urinary vanilmandelic acid and homovanillic acid by high-performance liquid chromatography with electrochemical detection following extraction by ion-exchange and ionmoderated partition. J Chromatogr 336:173-188

Borg S, Kvande H, Valverius P (1986): Clinical conditions 
and central dopamine metabolism in alcoholics during acute withdrawal under treatment with different pharmacological agents. Psychopharmacology 88:12-17

Bowers MB (1973): 5-Hydroxyindole acetic acid (5H-IAA) and homovanillic acid (HVA) following probenecid in acute psychotic patients treated with phenothiazines. Psychopharmacologia 28:309-318

Bowers MB (1974): Central dopamine turnover in schizophrenic syndromes. Arch Gen Psychiatr 31:50-54

Bowers MB, Heninger GR, Sternberg D, Meltzer HY (1980): Clinical processes and central dopaminergic activity in psychotic disorders. Commun Psychopharmacol 4:177188

Breier A, Davis OR, Buchanan RW, Moricle LA, Munson RC (1993): Effects of metabolic perturbation on plasma homovanillic acid in schizophrenia. Relationship to prefrontal cortex volume. Arch Gen Psychiatr 50:541-550

Bunney WE Jr, Hamburg DA (1963): Methods for reliable longitudinal observation of behavior. Arch Gen Psychiatry 9:280-294

Carlsson A, Lindqvist M (1963): Effect of chlorpromazine and haloperidol on formation of 3-methoxytyramine and metanephrine in mouse brain. Acta Pharmacol Toxicol 20:140-144

Contreras SA, Maas JW, Seleshi E, Bowden CL (1987): Increase in human urine homovanillic acid concentration after neuroleptic treatment is the same with or without debrisoquin administration. Arch Gen Psychiatr 44:1109-1110

Contreras SA, Maas JW, Seleshi E, Bowden CL (1988): Urine and plasma levels of dopamine metabolites in response to apomorphine and neuroleptics in schizophrenics. Biol Psychiatr 24:818-822

Crowley TJ, Hoehn MM, Rutledge CO, Stallings MA, Heaton RK, Sundell S, Stilson D (1978): Dopamine excretion and vulnerability to drug-induced parkinsonism. Arch Gen Psychiatr 35:97-104

Csernansky JG, Faull K-F, Pfefferbaum A (1988a): Seasonal changes of CSF monoamine metabolites in psychiatric patients: What is the source? Psychiatr Res 25:361-363

Csernansky JG, Melletin J, Beauclair L, Lombrozo L (1988b): Mesolimbic dopaminergic supersensitivity following electrical kindling of the amygdala. Biol Psychiatr 35: $375-$ 380

Culter NR, Jeste DV, Karoum F, Wyatt RJ (1982): Low-dose apomorphine reduces serum homovanillic acid concentrations in schizophrenic patients. Life Sci 30:753-756

Davidson M, Giordani AB, Mohs RC, Mykytyn VV, Platt S, Aryan ZS, Davis KL (1987): Control of exogenous factors affecting plasma homovanillic acid concentration. Psychiatr Res 20:307-312

Davidson M, Kahn RS, Powchik P, Warne P (1991): Changes in plasma homovanillic acid concentrations in schizophrenic patients following neuroleptic discontinuation. Arch Gen Psychiatr 48:73-76

Davidson M, Davis KL (1988): Comparison of plasma homovanillic acid concentrations in schizophrenic patients and normal controls. Arch Gen Psychiatr 45:561-563

Davila R, Manero E, Zumarraga M, Andia I, Schweitzer JW, Friedhoff AJ (1988): Plasma homovanillic acid as a pre- dictor of response to neuroleptics. Arch Gen Psychiatr 45:564-567

Davis KL, Davidson M, Mohs RC, Kendler KS, Davis BM, Johns CA, DeNegris Y, Horvath TB (1985): Plasma homovanillic acid concentration and the severity of schizophrenic illness. Science 227:1601-1602

Davis KL, Kahn RS, KO G, Davidson M (1991): Dopamine in schizophrenia: A review and reconceptualization. Am J Psychiatr 148:1474-1486

Dawson ME, Nuechterlein KH, Schell AM, Gitlin M, Ventura J. (1994): Autonomic abnormalities in schizophrenia: state or trait indicators. Arch Gen Psychiatr 51:813-824

Doran AR, Boronow J, Weinberger DR, Wolkowitz OM, Breier A, Picker D (1987): Structural brain pathology in schizophrenia revisited: Prefrontal cortex pathology is inversely correlated with cerebrospinal fluid levels of homovanillic acid. Neuropsychopharmacology 1:25-32

Doran AR, Labarca R, Wolkowitz OM, Roy A, Douillet P, Pickar D (1990): Circadian variation of plasma homovanillic acid levels is attenuated by fluphenazine in patients with schizophrenia. Arch Gen Psychiatr 47:558563

Elchisak MA, Polinsky RJ, Ebert MH, Powers KJ, Kopin IJ (1978): Contribution of plasma homovanillic acid (HVA) to urine and cerebrospinal fluid HVA in the monkey and its pharmacokinetic disposition. Life Sci 23:23392348

Elsworth JD, Leahy DJ, Roth RH, Redmond DE Jr (1987): Homovanillic acid concentrations in brain, CSF and plasma as indicators of central dopamine function in primates. J Neur Transm 68:51-62

Frecska E, Perenyi A, Bagdy G, Revai K (1985): CSF dopamine turnover and positive schizophrenic symptoms after withdrawal of long-term neuroleptic treatment. Psychiatr Res 16:221-226

Garelis E, Young SN, Lal S, Sourkes TL (1974): Monoamine metabolites in lumbar CSF: The question of their origin in relation to clinical studies. Brain Res 79:1-8

Gerhardt G, Drebing C, Freedman R (1986): Simultaneous determination of free homovanillic acid, (3-Methoxy-4hydroxyphenyl) ethylene glycol, and vanilmandelic acid in human plasma by high-performance liquid chromatography coupled with dual-electrode coulometric electrochemical detection. Anal Chem 58:2879-2883

Glazer WM, Bowers MB, Charney DS, Heninger GR (1989): The effect of neuroleptic discontinuation on psychopathology, involuntary movements, and biochemical measures in patients with persistent tardive dyskinesia. Biol Psychiatr 26:224-233

Grenhoff J, Nisell M, Ferre S, Aston-Jones G, Svensson TH (1993): Noradrenergic modulation of midbrain dopamine cell firing elicited by stimulation of the locus coeruleus in the rat. J Neural Transm 93:11-25

Gur RE, Mozley PD, Resnick SM, Mozley LH, Shtasel DL, Gallagher F, Arnold SM, Karp JS, Alavi A, Reivich M, Gur RC (1995): Resting cerebral glucose metabolism in first-episode and previously treated patients with schizophrenia relates to clinical features. Arch Gen Psychiatr 52:657-667

Haroutunian V, Knott P, Davis KL (1988): Effects of mesocor- 
tical dopaminergic lesions upon subcortical dopaminergic function. Psychopharmacol Bull 24:341-344

Hoedtke R, Rogawski U, Wurtman RJ (1974): Effect of selective destruction of central and peripheral catecholamine-containing neurons with 6-hydroxydopamine on catecholamine excretion in the rat. $\mathrm{Br} \mathrm{J}$ Pharmacol 51:265-270

Hornykiewicz O (1982): Brain catecholamines in schizophrenia-A good case for noradrenaline. Nature 299:484-486

Houston JP, Maas JW, Bowden CL, Contreras SA, McIntyre KL, Javors MA (1986): Cerebrospinal fluid HVA, central brain atrophy and clinical state in schizophrenia. Psychiatr Res 19:207-214

Hsiao JK, Colison J, Bartko JJ, Doran AR, Konicki PE, Potter WZ, Pickar D (1993): Monoamine neurotransmitter interactions in drug-free and neuroleptic-treated schizophrenics. Arch Gen Psychiatr 50:606-614

Javaid JI, Sharma RP, Janicak PG, Davis JM (1990): Plasma HVA in psychiatric patients: Longitudinal studies. Psychopharmacol Bull 26:361-365

Jennings WS, Schulz SC, Narasimhachari N, Hamer RM, Friedel RO (1985): Brain ventricular size and CSF monamine metabolites in an adolescent inpatient population. Psychiatr Res 16:87-94

Kahn RS, Davidson M (1993): On the value of measuring dopamine, norepinephrine and their metabolites in schizophrenia. Neuropsychopharmacology 8:93-95

Karoum F, Karson CN, Bigelow LB, Lawson WB, Wyatt RJ (1987): Preliminary evidence of reduced combined output of dopamine and its metabolites in chronic schizophrenia. Arch Gen Psychiatr 44:604-607

Karson CN, Garcia-Rill E, Biedermann J, Mrak RE, Husain MM, Skinner RD (1991): The brain stem reticular formation in schizophrenia. Psychiatry Res (Neuroimaging) 40:31-48

Kendler KS, Mohs RC, Davis KL (1983): The effects of diet and physical activity on plasma homovanillic acid in normal human subjects. Psychiatr Res 8:215-223

Kopin IJ, Oliver JA, Polinsky RJ (1988a): Relationship between urinary excretion of homovanillic acid and norepinephrine metabolites in normal subjects and patients with orthostatic hypotension. Life Sci 43:125131

Kopin IJ, Bankiewicz KS, Harvey-White J (1988b): Assessment of brain dopamine metabolism from plasma HVA and MHPG during debrisoquin treatment: Validation in monkeys treated with MPTP. Neuropsychopharmacology 1:119-125

Koreen AR, Lieberman J, Alvir J, Mayerhoff D, Loebel A, Chakos M, Amin F, Cooper T (1994): Plasma homovanillic acid levels in first-episode schizophrenia. Arch Gen Psychiatr 51:132-138

Lambert GW, Eisenhofer G, Jennings GL, Esler MD (1993): Regional HVA production in humans. Life Sci 53:63-75

Lambert GW, Eisenhofer G, Esler MD (1994): The influence of aging on the plasma concentration and renal clearance of homovanillic acid. Psychoneuroendocrinology 19:33-41

Lewine RR, Risch SC, Risby E, Stripetic M, Jewart D, Eccard M, Caudle J, Pollard W (1991): Lateral ventricle-brain ratio and balance between CSF HVA and 5-HIAA in schizophrenia. Am J Psychiatr 148:1189-1194

Lindström LH (1985): Low HVA and normal 5-HIAA CSF levels in drug-free schizophrenic patients compared to healthy volunteers: Correlations to symptomatology and family history. Psychiatr Res 14:265-273

Linnoila M, Oliver J, Adinoff B, Potter WZ (1988): High correlations of norepinephrine, dopamine, and epinephrine and their major metabolic excretion rates. Arch Gen Pyschiatr 45:701-704

Lipska BK, Jaskiw GE, Chrapusta S, Karoum F, Weinberger DR (1992): Ibotenic acid lesion of the ventral hippocampus differentially affects dopamine and its metabolites in the nucleus accumbens and prefrontal cortex in the rat. Brain Res 585:1-6

Lipska BK, Weinberger DR (1993): Delayed effects of neonatal hippocampal damage on haloperidol-induced catalepsy and apomorphine-induced stereotypic behaviors in the rat. Dev Brain Res 75:312-222

Lipska BK, Jaskiw GE, Weinberger DR (1994): The effects of combined prefrontal cortical and hippocampal damage on dopamine-related behaviors in rats. Pharmacol Biochem Behav 48:1053-1057

Lipska BK, Chrapusta SJ, Egan MF, Weinberger DR (1996) (in press, a): Neonatal excitotoxic ventral hippocampal damage alters dopamine response to mild repeated stress and to chronic haloperidol. Synapse.

Lipska BK, Jaskiw GE, Braun AR, Weinberger DR (1996) (in press, b): Prefrontal cortical and hippocampal modulation of haloperidol-induced catalepsy and apomorphineinduced stereotypic behaviors in the rat. Biol Psychiatr

Losonczy MF, Song IS, Mohs RC, Mathé AA, Davidson M, David BM, Davis KL (1986): Correlates of lateral ventricular size in chronic schizophrenia: II. Biological measures. Am J Psychiatr 143:1113-1118

Maas, JW, Hattox SE, Martin DM, Landis DH (1979): A direct method for determining dopamine synthesis and output of dopamine metabolites from brain in awake animals. J Neurochem 32:839-843

Maas JW, Contreras SA, Seleshi E, Bowden CL (1988): Dopamine metabolism and disposition in schizophrenic patients: Studies using debrisoquin. Arch Gen Psychiatr 45:553-559

Maas JW, Contreras SA, Miller AL, Berman N, Bowden CL, Javors MA, Seleshi E, Weintraub SE (1993a): Studies of catecholamine metabolism in schizophrenia/psychosis: I. Neuropsychopharmacology 8:97-109

Maas JW, Contreras SA, Miller AL, Berman N, Bowden CL, Javors MA, Seleshi E, Weintraub SE (1993b): Studies of catecholamine metabolism in schizophrenia/psychosisII. Neuropsychopharmacology 8:111-116

Meltzer HY (1991): The mechanism of action of novel antipsychotic drugs. Schizophr Bull 17:263-287

Miller AL, Keenan RW, Maas JW, Asch RH (1987): Disposition of homovanillic acid in the primate. Metabol Brain. Dis 2:207-212

Moleman P, Bruinvels J, van Valkenburg CFM (1978): Haloperidol inhibits the disappearance of acidic metabolites from the rat striatum. J Pharm Pharmacol 30:583-585

Muscettola G, Barbato G, de-Bartolomeis A, Monteleone P, 
Pickar D (1990): Plasma HVA, tardive dyskinesia and psychotic symptoms in long-term drug-free inpatients with schizophrenia. Psychiatr Res 33:259-267

Nybåck H, Berggren B-M, Hindmarsh 1, Sedvall G, Wiesel F-A (1983): Cerebroventricular size and cerebrospinal fluid monoamine metabolites in schizophrenic patients and healthy volunteers. Psychiatr Res 9:301-308

Pandey RS, Rao BSS, Subash MN, Subba Krishinu DK, Srinivas KN (1987): Central dopamine and serotonin turnover in schizophrenia. Ind J Psychiatr 29:203-212

Pickar D (1988): Perspectives on a time-dependent model of neuroleptic action. Schizophr Bull 14:255-268

Pickar D, Labarca RE, Doran AR, Wolkowitz OM, Roy A, Breier A, Linnoila M, Paul SM (1986): Longitudinal measurement of plasma homovanillic acid levels in schizophrenic patients: Correlation with psychosis and response to neuroleptic treatment. Arch Gen Psychiatr 43:669-676

Pickar D, Breier A, Hsiao JK, Doran AR, Wolkowitz OM, Pato CN, Konicki PE, Potter WZ (1990): Cerebrospinal fluid and plasma monoamine metabolites and their relation to psychosis: Implications for regional brain dysfunction in schizophrenia. Arch Gen Psychiatr 47:641648

Post RM, Fink E, Carpenter WT, Goodwin FK (1975): Cerebrospinal fluid amine metabolites in acute schizophrenia. Arch Gen Psychiatr 32:1063-1069

Potter WZ, Rudorfer MV, Pickar D, Linnoila M (1984): Effects of psychotropic drugs on neurotransmitters in man. Life Sci 41:817-820

Pycock CJ, Kerwin RW, Carter CJ (1980): Effect of lesion of cortical dopamine terminals on subcortical dopamine in rats. Nature 186:74-75

Randrup A, Munkvad I (1972): Evidence indicating an association between schizophrenia and dopamine hyperactivity in the brain. Orthomol Psychiatr 1:2

Rimon R, Roos BE, Rakkolainen V, Alanen Y (1971): The content of 5-hydroxyindoleacetic acid and homovanillic acid in the cerebrospinal fluid of patients with acute schizophrenia. J Psychosom Res 15:375-378

Scatton B, Worms P, Lloyd KG, Bartholini G (1982): Cortical modulation of striatal function. Brain Res 232:331-343

Scheinin H (1986): Enhanced noradrenergic neuronal activity increases homovanillic acid levels in cerebrospinal fluid. J Neurochem 47:665-667

Scheinin M, Chang W-H, Kirk JL, Linnoila M (1983): Simultaneous determination of 3-methoxy-4-hydroxyphenylglycol 5-hydroxyindolacetic acid, and homovanillic acid in CSF with high performance liquid chromatography using electrochemical detection. Anal Biochem 131:246253

Sedvall G, Wode-Helgodt B (1980): Aberrant monoamine metabolite levels in cerebrospinal fluid and family history of schizophrenia: Their relationship in schizophrenic patients. Arch Gen Psychiatr 37:1113-1116

Seeman P (1992): Dopamine receptor sequences-Therapeutic levels of neuroleptics occupy $\mathrm{D}_{2}$ receptors, clozapine occupies $\mathrm{D}_{4}$. Neuropsychopharmacology 7:261-284

Sharma RP, Javaid JI, Janicak PG, Comaty J, Davis JM (1989): Plasma and CSF HVA before and after pharmacological treatment. Psychiatr Res 28:97-104.
Sharma RP, Javaid JI, Janicak PG, Davis JM, Fauli K (1993): HVA in the CSF: Pattern of response after 4 weeks of neuroleptic treatment. Biol Psychiatr 34:128-134

Sourkes TL (1973): On the origin of homovanillic acid (HVA) in the cerebrospinal fluid. J Neural Transm 34:153-157

Spitzer RL, Endicott J (1979): The Schedule for Affective Disorders and Schizophrenia-Lifetime version, ed 3. New York, New York State Psychiatric Institute, Biometrics Research

Stanley M, Traskman-Bendz L, Dorovini-Zis K (1985): Correlation between aminergic metabolites simultaneously obtained from human CSF and brain. Life Sci 37:12791286

Sternberg DE, Heninger GR, Roth RH (1983): Plasma homovanillic acid as an index of brain dopamine metabolism: Enhancement with debrisoquin. Life Sci 32:2447-2452

Tandon R, Shipley JE, Greden JF, Mann MA, Eisner WH, Goodson J (1991): Muscarinic cholinergic overactivity in schizophrenia: Relationship to positive and negative symptoms. Schizophr Res 4:23-30

van Kammen DP (1979): The dopamine hypothesis of schizophrenia revisited. Psychoneuroendocrinology 4:37-46

van Kammen DP (1991): The biochemical basis of relapse and drug response in schizophrenia: Review and hypothesis. Psychol Med 21:881-895

van Kammen DP, Sternberg DE (1980): CSF studies in schizophrenia. In Wood JH (ed), Neurobiology of Cerebrospinal Fluid, vol I, New York, Plenum, pp 719-742

van Kammen DP, van Kammen WB (1984): The amphetamine challenge test in schizophrenia: A stress response? In Usdin E, Kvetnansky R, Axelrod J (eds), Stress: The Role of Catecholamines and Other Neurotransmitters, New York, Gordon \& Breach, pp 957-966

van Kammen DP, Docherty JP, Bunney WE Jr (1982a): Prediction of early relapse after pimozide discontinuation by response to $\mathrm{d}$-amphetamine during pimozide treatment. Biol Psychiatr 17:233-242

van Kammen DP, Sternberg DE, Hare TA, Waters R, Bunney WE Jr (1982b): CSF levels of gamma-aminobutyric acid in schizophrenia. Arch Gen Psychiatr 39:91-97

van Kammen DP, Mann LS, Sternberg DE, Scheinin M, Ninan PT, Marder SR, van Kammen WB, Rieder RO, Linnoila M (1983): Dopamine beta hydroxylase activity and homovanillic acid in spinal fluid of schizophrenics with brain atrophy. Science 220:974-976

van Kammen DP, van Kammen WB, Mann LS, Seppala T, Linnoila M (1986): Dopamine metabolism in the cerebrospinal fluid of drug-free schizophrenic patients with and without cortical atrophy. Arch Gen Psychiatr 43: 978-983

van Kammen DP, Peters JL, van Kammen WB, Nugent A, Goetz KL, Yao J, Linnoila M (1989): CSF norepinephrine in schizophrenia is elevated prior to relapse after haloperidol withdrawal. Biol Psychiatr 26:176-181

van Kammen DP, Kelley ME, Gurklis J, Gilbertson MW, Yao JK, Peters JL (1995): Behavioral vs. biochemical prediction of relapse following haloperidol withdrawal in schizophrenia. Arch Gen Psychiatr 52:673-678

van Kammen DP, Kelley ME, Gurklis JA, Gilbertson MW, Yao JK, Condray R, Peters JL (1996): Predicting duration 
of clinical stability following haloperidol withdrawal in schizophrenia. Neuropsychopharmacology 14:275-283

van Kammen DP, Petty F, Kramer GL, Kelley ME, Yao JK, Gurklis JA, Peters JL (submitted): Clinical evidence that GABA is involved in schizophrenia: Plasma GABA correlates with brain morphology, CSF HVA, CSF 5-HIAA, negative symptoms, and premorbid functioning.

van Rossum JM (1966): The significance of dopamine-receptor blockade for the mechanism of action of neuroleptic drugs. Arch Int Pharmacodynamics 160:492-494

Weinberger DR (1987): Implications of normal brain development for the pathogenesis of schizophrenia. Arch Gen Psychiatr 44:660-669

Weinberger DR, Berman KF, Illowsky BP (1988): Physiological dysfunction of dorsolateral prefrontal cortex in schizophrenia. III. A new cohort and evidence for a monoaminergic mechanism. Arch Gen Psychiatr 45:609 615

Westerink BHC, Kikkert RJ (1986): Effects of various cen- trally acting drugs on the efflux of dopamine metabolites from the rat brain. J Neurochem 46:1145-1152

Whelton CL, Gupta RN, Cleghorn JM, Ballagh SR (1993): Influence of renal clearance on peripheral homovanillic acid measurements in healthy subjects and schizophrenic patients. Special issue dedicated to the memory of Professor John M. Cleghorn. Schizophr Res 11:33-40

Yeomans JS (1995): Role of tegmental cholinergic neurons in dopaminergic activation, antimuscarinic psychosis and schizophrenia. Neuropsychopharmacology 12:3-16

Zahn TP (1988): Studies of autonomic psychophysiology and attention in schizophrenia. Schizophr Bull 14:205-208

Zander KJ, Fischer B, Zimmer R, Ackenheil M (1981): Longterm neuroleptic treatment of chronic schizophrenic patients: Clinical and biochemical effects of withdrawal. Psychopharmacology 33:43-47

Zukin SR, Javitt DC (1992): The PCP/NMDA theory of schizophrenia. In Lindenmayer J-P, Kay SR (eds), New Biological Vistas on Schizophrenia, New York, Brunner/ Mazel, pp 222-238 